\title{
The knowledge of obstetric complications among primigravidae in a rural health centre in the district of Blantyre, Malawi
}

\author{
L Kumbani, University Certificate in Midwifery, MSc. Nursing (Wits), Kamuzu College of \\ Nursing, Blantyre, Malawi. \\ P Mc Inerney, PhD (Wits)
}

\section{Abstract}

An informed individual is better placed to make reasonable decisions. It is therefore of vital importance that women be knowledgeable about obstetric complications to enable them to respond appropriately to complications that may arise. This study aimed to explore primigravidae's knowledge of obstetric complications.

A descriptive study design was used to determine what knowledge primigravidae had of obstetric complications. Recognition of obstetric complications in pregnancy, during labour and after delivery and actions that participants would take if they developed any complications in pregnancy and after delivery were explored. Participants' actions were not sought for problems faced during labour because the researcher felt the participants would have little control of the situation with regard to choice during labour.

Methods: Participants were selected by means of purposive sampling from a population of pregnant women who fitted defined criteria attending antenatal clinic at a health centre. Thirty-three primigravidae from the rural setting with a gestation period between 28 and 42 weeks were interviewed.

Results: The findings showed that participants were more aware of obstetric complications that could occur in pregnancy than of complications that may occur during and after delivery. Participants had limited knowledge of complications that may need immediate treatment during all three periods. Eighty-two percent (95\% ci: 67-96) of the primigravidae had some knowledge and could make an informed decision to go to a health facility with pregnancy complications. Sixty-one percent (95\% ci: $42-79)$ of the primigravidae had knowledge and could make an informed decision to go to a health facility with complications after delivery. These findings have critical implications for the provision of information on obstetric complications. The information given should cover all three periods, with emphasis on those obstetric complications that require immediate treatment.

\section{Opsomming}

'n Ingeligte individu is in ' $n$ beter posisie om redelike besluite te neem. Dit is daarom van kardinale belang dat vroue kennis besit betreffende obstetriese komplikasies om sodoende in staat te wees om op te tree ingeval van komplikasies. Die studie het gepoog om die obstetriese komplikasies van primigrawidas te ondersoek

'n Beskrywende ontwerp vir die studie is benut om die kennis van primigrawidas betreffende obstetriese komplikasies, te bepaal. Herkenning van obstetriese komplikasies in swangerskap tydens en na die geboorte van die baba asook die aksies wat die deelnemers sou neem ingeval van enige komplikasies gedurende swangerskap en na die geboorte, is ondersoek. Die aksies van die deelnemers betreffende die probleme gedurende die geboorteproses is nie bestudeer nie weens die feit dat die navorser gevoel het dat deelnemers min kontrole oor die situasie van die uitoefening van keuses tydens geboorte het.

Metode: Deelnemers is deur middel van doelgerigte steekproefneming vanuit die populasie van swanger vroue wat die voorgeboorte kliniek by ' $\mathrm{n}$ gesondheidsentrum bygewoon het, en wat aan die gedefinieerde kriteria voldoen het, geselekteer. Onderhoude is met twee en dertig primigrawidas uit die plattelandse area met ' $n$ gestasie periode van tussen 28 en 42 weke gevoer.

Resultate: Die bevindinge het aangetoon dat deelnemers meer bewus was van obstetriese komplikasies tydens swangerskap as van komplikasies wat mag voorkom tydens en na die geboorte. Deelnemers het beperkte kennis van komplikasies wat onmiddellike behandeling gedurende al drie periodes benodig, gehad. Twee en tagtig persent $(95 \%$ ci: 67-96) van die primigrawidas het sekere kennis gehad en kon ingeligte besluite neem om na ' $n$ gesondheidsfasiliteit te gaan met swangerskapkomplikasies. Een en sestig persent (95\% ci: 42-79) van die primigrawidas het kennis gehad en kon ingeligte besluite neem om na 'n gesondheidsfasiliteit te gaan met komplikasies na die geboorte. Hierdie bevindinge het kritiese implikasies vir die voorsiening van inligting betreffende obstetriese komplikasies. Die inligting behoort gedurende al drie periodes verskaf te word, met die klem op daardie obstetriese komplikasies wat onmiddellike behandeling verg. 


\section{Introduction}

Attempts to address women's health problems and needs have been a major focus internationally. The United Nations dedicated 1985-1995 as the decade for women. The World Health Organisation declared World Health Day in 1998 a Safe Motherhood Day to highlight the worldwide plight suffered by women, especially during pregnancy and childbirth. The focus of the WHO declaration was mainly on developing countries (Lalonde 1998: 889). Malawi participated in the 1987 International Safe Motherhood Conference in Nairobi, Kenya and realised the need to urgently address maternal and child health problems. Maternal mortality is of great concern because "Every minute of every day at least one woman dies from complications of pregnancy and childbirth - more than 585,000 deaths every year" (Shane 1997:1). More than 99\% of these deaths occur in the developing countries (WHO 1996, in Post 1997: 2). The Malawi mortality ratio is estimated at $620 / 100,000$ live births. This translates into:

- about 3,000 women dying every year during pregnancy or childbirth;

- $\quad$ ten women die everyday;

- 45,000 women surviving, but living with chronic disability (Ngaiyaye and Safe Motherhood Project, un dated: 7). grammes worldwide is based on the implementation of the four pillars of Safe Motherhood. These are family planning, antenatal care, clean safe delivery and essential obstetric care (Maternal Health and Safe Motherhood Programme 1994: xi). In 1995 the Malawi Government set up a National Safe Motherhood Initiative. The overall goal of the programme is to reduce maternal deaths by half, to $310 / 100,000$, by the year 2001 , which was later changed to 2004. The Ministry of Health and Population and various non-governmental organisations are implementing the Safe Motherhood Initiative in all regions of $\mathrm{Ma}$ lawi. Various strategies have been planned to achieve this goal with the major focus being on community participation. One of the set strategies is information, education and communication (IEC) campaigns on pregnancy risks and appropriate actions to take (Malawi Safe Motherhood Programme, Malawi Safe Motherhood Project and Ministry of Health and Population 2000: 5). This is to empower individuals and families to identify what they can do for themselves. Studies consulted have shown that a community's awareness of obstetric complications usually increased women's use of health services, e.g. in Bolivia, women's knowledge of obstetric complications improved their utilisation of antenatal and family planning services from $45 \%$ to $77 \%$ and 0 to $27 \%$, respectively (Kwast 1995 : S72). Opoku et al. (1997: S205 - S206) and Olaniran et al. (1997: S88 - S89) had similar findings. Education campaigns resulted

\section{Table 1 : Pregnancy problems experienced by participants $(n=15)$}

\begin{tabular}{|c|c|c|}
\hline PROBLEM & $\mathbf{n}$ & TOTAL PERCENTAGE \\
\hline Abdominal pain & 3 & 20 \\
\hline Malaria / frequent attacks of malaria & 10 & 66.7 \\
\hline Oedema of legs/s'vollen feet & 2 & 13.3 \\
\hline Heart palpitations, dizziness due to anaemia ${ }^{*}$ & 1 & 6.7 \\
\hline Headache & 1 & 6.7 \\
\hline Severe headache & 1 & 6.7 \\
\hline Backache & 1 & 6.7 \\
\hline Severe abdominal pains and backache & 1 & 6.7 \\
\hline Depression (husband not pleased with pregnancy) & 1 & 6.7 \\
\hline Heart palpitations & 1 & 6.7 \\
\hline Chest pains & 1 & 6.7 \\
\hline
\end{tabular}

* This respondent was reporting from her personal experience.

The lifetime risk of maternal death for a Malawi woman is 20 . This means that one woman out of twenty is at risk of dying from pregnancy or childbirth during her lifetime (World Health Organisation and World Bank 1997: 1). This is alarming because childbirth is a natural process, which is expected to end happily with a healthy mother and newborn.

Reduction of maternal mortality by Safe Motherhood Pro- in an increase in women with obstetric complications utilising health care. The women are more likely to seek medical care for obstetrical complications if they know the causes, are aware of the seriousness of the complications and know what to do. Themmen (1995: 30) and Alisjahbana et al. (1995: S84) emphasise that women must be able to recognise the danger signs of obstetric complications for them to seek medical care. Studies 
by Gummi et al. (1997: S196) and Olaniran et al. (1997: S183) identified poor knowledge of obstetric complications as one of the barriers to seeking health care. In a study in Nigeria, haemorrhage was considered normal for cleansing the mother after delivery (Olaniran et al. 1997: S183). Castro et al. (2000: 683) described the relationship between lack of knowledge and maternal death, as pregnancy-related problems are considered normal. Women endure obstetric complications because the presenting signs and symptoms are not usually recognised as reason for concern.

Primigravidae, particularly the young are at a higher risk of dying from pregnancy and delivery complications (Bhatia 1993: 10). In a study done on maternal mortality in Malawi out of 118 deaths, $33 \%$ of the women were aged between 16 and 20 years average for developing countries at 620 . Around $80 \%$ of maternal deaths worldwide are due to five direct causes: haemorrhage (25\%), sepsis (15\%), unsafe abortion (13\%), eclampsia (12\%), obstructed labour ( $8 \%$ ) and other direct causes (including ectopic pregancy and anaesthesia accidents) $(8 \%)$ (Abouzar et al. 1996: 77; World Health Organization 1999: 13).

The major causes of maternal mortality in Malawi are similar to those in other developing countries. The identified immediate causes include complications of abortions (18\%), haemorrhage (24\%), obstructed labour/ruptured uterus (20\%), sepsis (24\%) and eclampsia (4\%) (Malawi Safe Motherhood Programme, Malawi Safe Motherhood Project and Ministry of Health and Population 2000: 4).

The Malawi National Safe Motherhood Programme was started in 1996. All the pillars of Safe Motherhood are being addressed

\section{Table 2 : Problems that may occur during pregnancy $(n=33)$}

\begin{tabular}{|l|c|c|}
\hline PROBLEM & n & PERCENTAGE \\
\hline Vaginal bleeding (APH) & 13 & 39 \\
\hline Malaria/Frequent attacks of malaria & 10 & 30 \\
\hline Breathlessness (severe anaemia) & 7 & 21 \\
\hline High blood pressure & 6 & 18 \\
\hline Swelling (oedema) & 3 & 9 \\
\hline Dizziness due to anaemia & 3 & 9 \\
\hline Fitting (eclampsia) & 2 & 6 \\
\hline Abdominal pains & 2 & 6 \\
\hline Heart palpitations & 2 & 6 \\
\hline Backache & 2 & 6 \\
\hline Abortion & 1 & 3 \\
\hline Leaking fluid (draining) & 1 & 3 \\
\hline Severe headache & 1 & 3 \\
\hline Abdominal and pubic pains & 1 & 3 \\
\hline Dizziness & 1 & 3 \\
\hline Painful legs & 1 & 3 \\
\hline
\end{tabular}

(Phoya et al. 1990 in Malawi National Safe Motherliood Programme, undated: 16). Girls aged 15 to 19 years are twice as likely to die during pregnancy or delivery compared to women aged 20 to 34 years (Safe Motherhood Fact Sheet: 2). This data supports the claims that adolescent girls have an increased risk of maternal death. Therefore it is important to inform primigravidae about obstetric complications to improve their recognition of complications. This is significant as a delayed decision or never making the decision to seek care when faced with obstetrical complications increases the women's probability of dying.

\section{Background to the problem}

According to Safe Motherhood an estimated 515000 maternal deaths occur globally and over half of these in Africa (Safe Motherhood Fact Sheet: 1). More than half a million maternal deaths occur each year in developing countries. The maternal mortality ratio averages around 440 in developing countries compared to 21 in developed countries (Abouzahr, 2000: 2). The maternal mortality ratio for Malawi is greater than the through different complementary programmes in Malawi. The last pillar includes the use of life-saving skills and timely emergency obstetric care when the need arises. This is the most important aspect in reducing maternal mortality, because if women are not assisted when complications arise, all the work done in the first three pillars will be of little use. The mother will either die or survive with a disability. This emphasises the point that "Availability and timely utilisation of high quality emergency obstetric care for complications has been described as the foundation of any programme to reduce maternal deaths" (Maine, 1993, in Simpson 1998: 6).

A survey done in Malawi showed that, while people had adequate knowledge of family planning, they had little awareness of the other pillars of Safe Motherhood and limited knowledge of obstetric complications (Matinga 1998: 5). Needs asessment surveys conducted in 1998 and 1999 revealed a severe lack of IEC materials and information on complications of pregnancy and childbirth in the clinics. In addition, there were low levels of knowledge amongst health workers- none could name all five complications and only $18 \%$ of people in the community recognised bleeding as a problem and none mentioned 
infection (Ngaiyaye and Safe Motherhood Project undated: 7). This necessitated the importance of empowering health workers and the community with knowledge through IEC interventions. This was pertinent as delay in seeking treatment was noted as a contributory factor to maternal mortality (Mwanza District Hospital 1999: 6; Safe Motherhood Project, draft 1999: 14). However, for women to seek health care timeously, they should be aware of the obstetric complications and know what to do when they occur.

While strategies to inform women about obstetric complications have been formulated and put in place, little is known about the extent to which these IEC strategies are effective. Studies consulted during a review of the literature showed that a community's awareness of obstetric complications usually increased women's use of health services (Kwast 1995: S72; Opuku et al. 1997: S205 - S206; Olaniran et al. 1997: S88S89). However, in this connection a study done in two districts make informed decisions.

\section{The Setting}

The study was conducted in a rural health centre in Blantyre district. The district has 21 health centres, with eight in the urban and thirteen in the rural areas. One urban health centre and one rural health centre were randomly selected from the eight and thirteen centres respectively. For the purpose of this article only the findings of the rural centre will be described. The rural health centre that was chosen offers free services.

\section{Research design}

A descriptive research design was used to determine what primigravidae knew about obstetric complications that may occur during pregnancy, labour and the puerperium. This de-

\section{Figure 1: Problems needing immediate treatment during pregnancy}

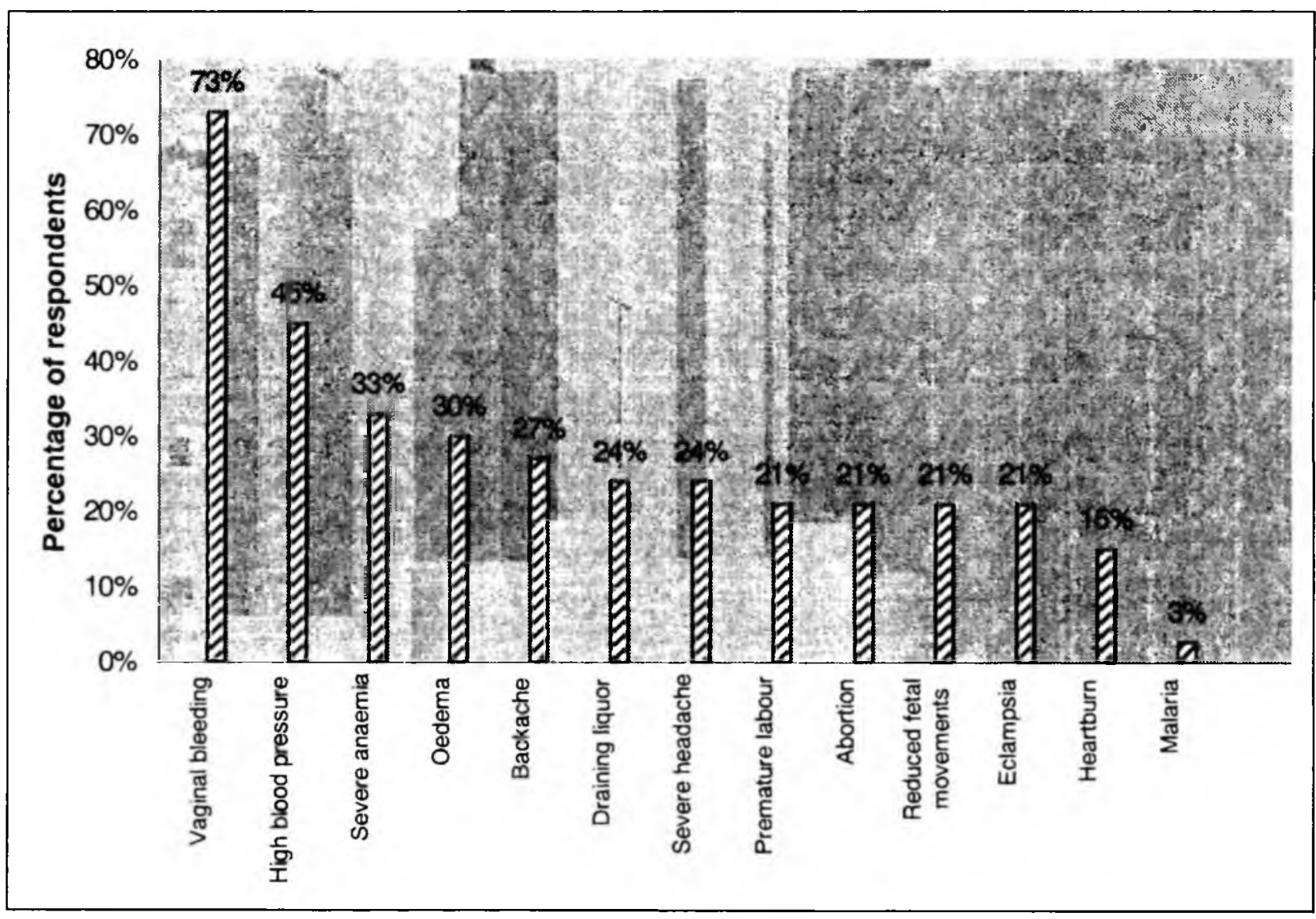

in Malawi by Simpson (1998: 15) demonstrated that opportunities to increase women's awareness of danger signs were not being fully utilised. She commented that only $6 \%$ and less than $1 \%$ of users $(n=464)$ reported that they had received information about bleeding and fever respectively on discharge after delivery.

It was against this background that this study attempted to explore whether primigravidae were being provided with adequate information about obstetric complications to enable them sign was appropriate because it enabled the researchers to determine the conditions the primigravidae identified as complications and the conditions for which they would seek immediate treatment (Polit \& Hungler 1991:19).

\section{The Population}

Women who were pregnant at the time of the study who were attending antenatal clinic at the selected health centre and who 
fitted defined criteria were selected. The criteria were:

- $\quad$ primigravida in whom a viable outcome was expected; - $\quad$ gestation period was between 28 and 42 weeks.

Only primigravidae were used in the study to eliminate the influence of previous childbirth experiences.

\section{The Sample}

Purposive sampling was used to select primigravidae who met the stated criteria. The sample size was determined in consultation with a statistician. A sample size of 33 primigravidae was chosen based on the assumption that $60 \%$ had sufficient knowledge to know when to go to hospital and this estimate was accurate to within $10 \%$, with a confidence level of $95 \%$.

Research Instrument main researcher (L.K.) conducted interviews with women attending antenatal clinic. The women were approached after their antenatal visit and invited to participate in the study. The participants were interviewed in a room in the clinic that had been made available to the researcher for the purpose of the interviews.

\section{Data Analysis}

Data were analysed manually. Descriptive and inferential statistics were employed to describe the findings.

\section{Validity and Reliability}

Content validity was maintained through consultation with experts in the field. A pilot study was conducted to pretest the validity and reliability of the instrument. Five women who met the inclusion criteria of the study were interviewed by the main

\section{Table 3: Problems which may occur during delivery of the baby $(n=33)$}

\begin{tabular}{|l|c|c|}
\hline \multicolumn{1}{|c|}{ PROBLEM } & n & PERCENTAGE \\
\hline Bleeding / heavy bleeding & 6 & 18 \\
\hline Caesarean section & 2 & 6 \\
\hline Episiotomy & 2 & 6 \\
\hline Obstructed labour & 1 & 3 \\
\hline Breech presentation & 1 & 3 \\
\hline Transverse lie & 1 & 3 \\
\hline Fitting & 1 & 3 \\
\hline Difficult delivery & 1 & 3 \\
\hline Delivering on the way to hospital & 1 & 3 \\
\hline Flat baby- laziness of the mother & 1 & 3 \\
\hline
\end{tabular}

The researcher developed the instrument and the items soliciting obstetric complications were sourced from the existing literature. Information collected included primigravidae's demographic and obstetric data and information about obstetric complications in pregnancy, during and after birth. The interview schedule consisted of three sections. Section A contained six questions related to demographic data; Sections B and D had nine questions related to obstetric information and Section $C$ had thirteen questions related to knowledge and actions about obstetric complications in pregnancy, during and after birth. The interview was chosen as a means of data collection because many women are illiterate and therefore unable to complete a questionnaire.

\section{Data Collection}

Data were collected over a six week period during which the researcher. No problems were experienced in answering the questions and therefore no changes were made to the interview schedule. In addition the main researcher (L.K.) conducted the interviews and this promoted the consistency in which the interviews were conducted.

\section{Ethical Considerations}

All eligible primigravidae were asked to participate and verbal consent was obtained from each participant prior to the interview. A letter providing information about the research was read to the participants and they were assured that they were free to withdraw from the study at any time. Permission to conduct the study was obtained from the National Health Sciences Research Committee as well as from the District Health Officer-South, in Malawi. Ethical clearance from the Committee for Research on Human Subjects of the University of 


\section{Findings and discussion of findings \\ Demographic data}

The age range of the participants was $16-25$ years with a mean age of 18.9 and a standard deviation of 1.8. The actual age when women start childbearing is an important demographic and social indicator because it influences the number of children women will have if they are not using contraception; an aspect associated with increased health risks for the mother (National Statistical Office 1994: 25). Maternal age is also significant because it is important in determining obstetric outcome. Teenage primigravidae are at increased risk during pregnancy, with poor obstetric outcome (Verma and Das 1997: 3). Maternal mortality is increased in teenage primigravidae (Ado- and four in the third trimesters respectively. This suggests that most women start attending antenatal clinic late. Therefore, there is a need to establish alternative ways of communicating, early in pregnancy, the signs and symptoms of obstetric complications, and what actions women should take. The largest group of participants, $23(69.7 \%)$, had been to the clinic three to four times. One participant made the most visits (7-8). The number of visits the primigravidae made to the clinic did not necessarily improve their knowledge of obstetric complications. For example the participant who made the most visits did not know of any obstetric complications during pregnancy, labour and the puerperium. These results indicate that it is not the number of visits to the clinic that will empower women with knowledge about obstetric complications. They need to be given sufficient information for them to know about obstetric complications, and when to go to a health facility. Fifteen (45\%) of the participants reported that they had experienced problems during the pregnancy. Malaria was the most mentioned problem (see Table 1). Almost all, 14 (93\%) of the participants

\section{Table 4: Problems that may occur after the birth of the baby $(n=33)$}

\begin{tabular}{|l|c|c|}
\hline PROBLEM & n & PERCENTAGE \\
\hline Sepsis & 10 & 30 \\
\hline Postpartum haemorrhage & 8 & 24 \\
\hline Retained placenta & 1 & 3 \\
\hline Fatigue & 1 & 3 \\
\hline Malaria & 1 & 3 \\
\hline After pains & 1 & 3 \\
\hline Draining liquor & 1 & 3 \\
\hline
\end{tabular}

lescence and pregnancy: 1 ).

Teenage primigravidae therefore need to be given specific information about obstetric complications that promotes awareness of their risk status, as they require better obstetric and neonatal care.

The majority of the participants, $29(87.9 \%)$ had primary level education and only four $(12.1 \%)$ had attended secondary school. All of the participants were unemployed and two (6.1\%) had dropped out of school because of the pregnancy. The majority of the participants, $25(76 \%)$, were married. The eight (24\%) participants who were single were also unemployed. Information provided to this group needs to take into consideration the socio-economic status of the women for it to be relevant. For example, information about actions to be taken to prevent delays in reaching a health facility should a complication develop, should be discussed.

\section{Antenatal clinic attendance and problems experienced}

Most, $27(82 \%)$ of the participants started attending an antenatal clinic in the second trimester while two booked in the first who had problems received treatment except one, who stated that she did not inform the clinic staff.

\section{Knowledge of obstetric complications}

Firstly, the participants were asked to name some problems which might occur during pregnancy, labour and the puerperium. Thereafter, they were asked to state whether certain problems were associated with pregnancy, labour and the puerperium. This was to cater for those participants who could have had problems with the former questions because they had forgotten.

\section{Knowledge related to antepartum period}

Five participants (15\%) stated that they did not know any problems that could occur during pregnancy. Three frequently mentioned problems were vaginal bleeding, malaria and severe anaemia (refer Table 2).

The frequencies of actual complications that could develop were generally low (refer Table 2). The highest, vaginal bleeding, was mentioned by only 13 (39\%) of the participants. Yet all of these - bleeding, anaemia and eclampsia - are among the danger signs identified by the Safe Motherhood Initiative.

Malaria, mentioned by $10(30 \%)$ of the participants, is not spe- 
cific to pregnancy. It was probably mentioned because of its frequent occurrence in pregnant women in Malawi. Exacerbation or relapse of malaria is common during pregnancy (Bennett and Brown 1999:305). This is supported by Brabin (1983 in Kuate Defo 1997:1033), who stated that "pregnant women lose part of their acquired immunity, and malaria attacks are therefore often more severe in pregnancy".

Five (15\%) of the participants identified minor disorders of pregnancy as complications that could occur. This may be because these participants were not aware of the physiological changes of pregnancy and therefore did not understand what was happening. It also suggests that these participants did
This suggests that not much emphasis is made on this during health education. It may be because eclampsia is responsible for about $4 \%$ of maternal deaths in Malawi. Abortion leads to $18 \%$ of maternal deaths in Malawi, but it was identified by only seven $(21 \%)$ participants. This finding implies a need to emphasise serious obstetric complications that need immediate treatment when providing information. This is important for the primigravidae and the community as a whole, to motivate them to appropriately seek immediate care for complications that need prompt treatment. Sufficient knowledge about obstetric complications is necessary for the primigravidae to make informed decisions that may help to reduce maternal morbidity

\section{Figure 2: Labour problems identified as needing immediate treatment}

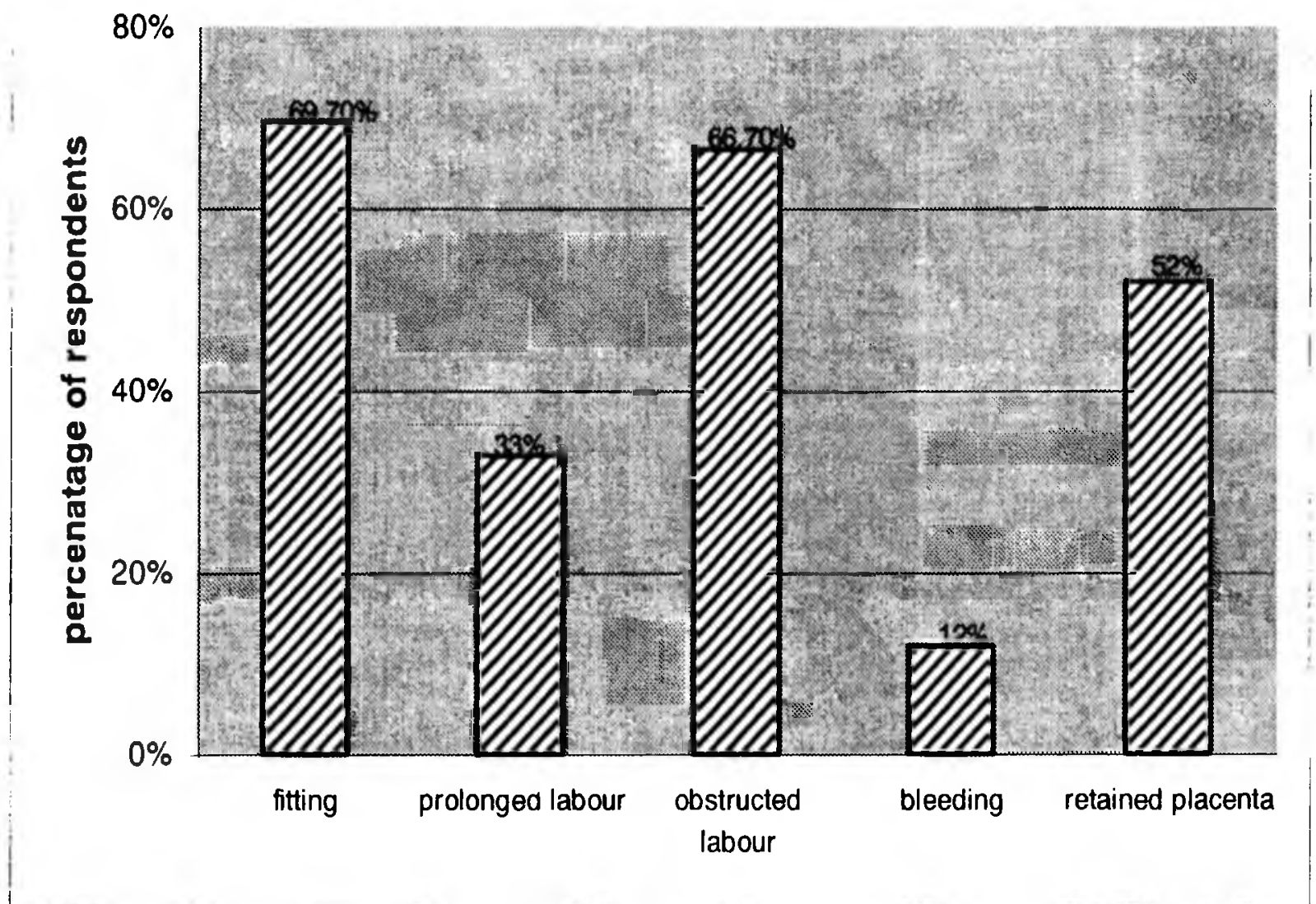

not know the likely complications that could develop.

When the participants were asked to state problems that needed immediate treatment, the majority, 24 (73\%), mentioned that vaginal bleeding needed immediate treatment. Fig. 1 depicts the range of responses given by participants.

Four $(12 \%)$ participants did not know of any problems that needed immediate treatment.

Heartburn and backache were identified by 14 (42\%) of the participants as requiring immediate treatment. Both heartburn and backache are minor discomforts of pregnancy (Bennett and Brown 1999: 204 - 205). They do not require immediate treatment, but education and advice on how to prevent or overcome them. Severe headache, which is considered a warning sign of eclampsia in patients with high blood pressure, was identified by only eight (24\%) of the participants. Eclampsia, in spite of being a life threatening condition, was mentioned by only seven $(21 \%)$ participants as needing immediate treatment. and mortality in this group.

Participants gave three reasons for the complications needing immediate treatment. These were: to prevent death of the mother $(n=29)$, avoid the effects of the problems $(n=8)$ and to regain good health $(n=5)$. Fear of the woman's death was the reason frequently given by participants, $29(87.8 \%)$, for seeking immediate treatment. This finding probably signifies that the primigravidae were aware that many women die during childbirth as reflected in the high mortality rate in Malawi. All participants stated they would go to a health facility if they experienced problems in pregnancy. Of these, $11(33 \%)$ linked a time factor by stating that they would go quickly/immediately and $13(39 \%)$ gave a reason for going. Three participants gave both a reason for going to the hospital and the time factor.

Participants who stated that they would go quickly and/or gave the reason for going, were deemed to have had access to information that would alert them to the importance of making this 
decision. Eight-two percent (95\% confidence interval: 67-96) of primigravidae had some knowledge and could make an informed decision to go to the hospital.

\section{Knowledge related to the intrapartum period}

Fourteen ( $42 \%$ ) of the participants could name problems that could occur during the birth. Bleeding was the only problem that was mentioned six times compared to most that were stated once only (see Table 3 ). edgeable about the problems themselves (Table 3) they could not know about its management. All the problems listed in Fig.2 require immediate treatment.

Information on obstetric complications should be given in such a way that it will promote awareness of problems requiring prompt treatment. A study done by the Safe Motherhood Project (1999: 44) found no clear differentiation between serious obstetric complications needing prompt treatment (danger signs in pregnancy) and those that did not.

The reasons given by participants for seeking immediate treat-

\section{Figure 3 : Postpartum problems identified as needing immediate treatment}

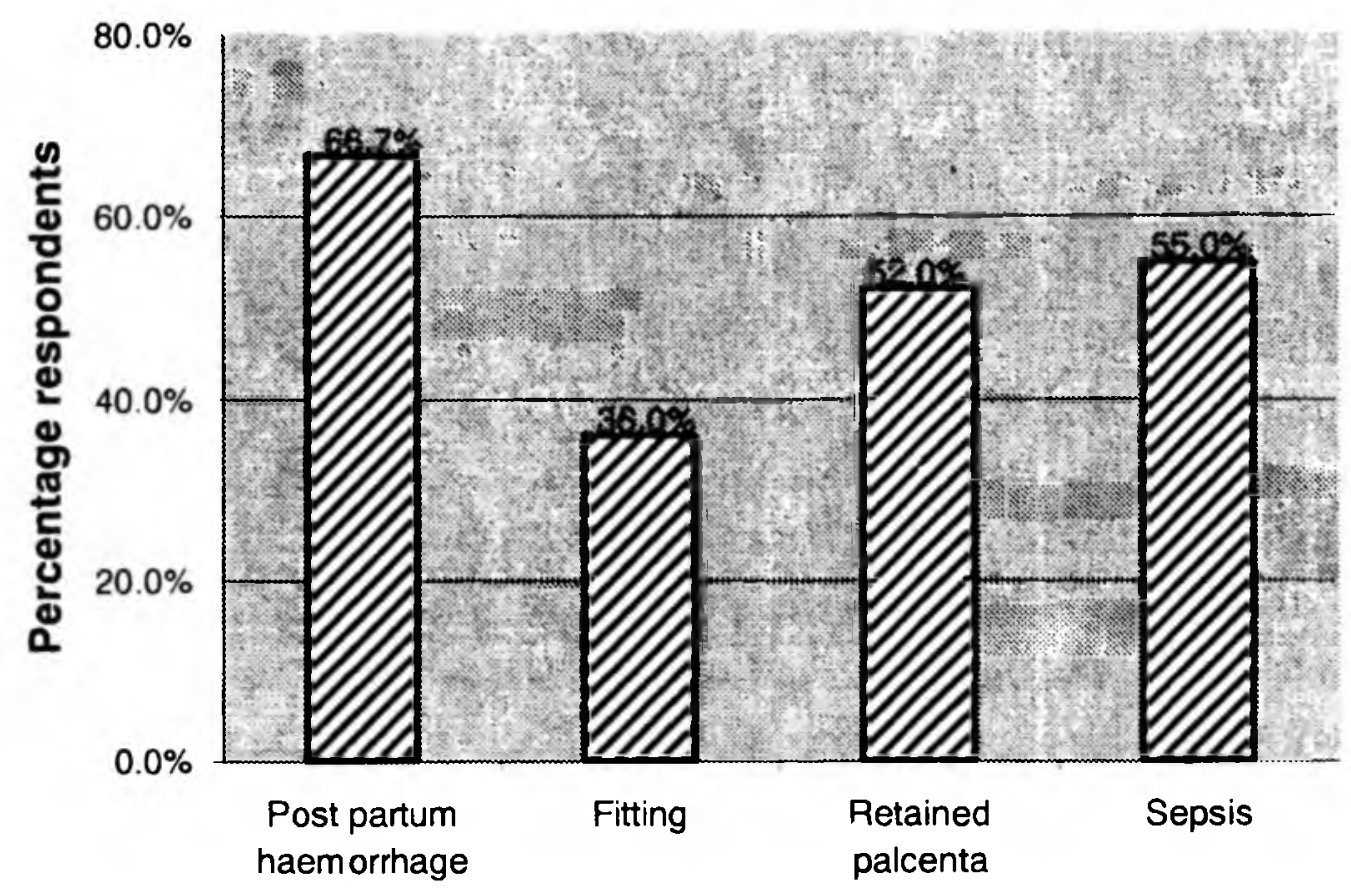

Fitting and obstructed labour were identified by only one participant respectively. Caesarean Section and episiotomy, identified by the participants as problems, are actually obstetric interventions. These findings indicate that even the fourteen participants who answered the question had a low level of awareness of the complications that might develop during delivery of the baby. Five (15\%) of the participants did not know any problems that needed immediate treatment. This is worrying, because cultural beliefs regarding the causes of complications are still strong (Safe Motherhood Project, 1998: 15) and may delay the women in seeking emergency care. According to Thaddeus and Maine, obstructed labour is viewed as punishment. "It is believed that the woman must confess her sins so that delivery will progress smoothly, thus precluding the decision to seek medical care for the complication" (Thaddeus and Maine 1994: 1097).

The participants' identification of problems that needed immediate treatment was low (refer Fig.2). Five (15\%) of the participants stated that they did not know the problems that needed immediate treatment.

This was probably a reflection of the participants' lack of knowledge about obstetric complications that could occur during the birth of the baby. Since the participants were not knowl- ment were to prevent prolonged suffering $(n=3)$; for the mother to get well $(n=3)$; avoid death of the mother $(n=19)$ and baby $(n=5)$. Again fear of death of the woman was highlighted by most participants, $19(57.6 \%)$, as the reason for seeking immediate treatment, in comparison with the rest of the reasons. Twelve $(36 \%)$ of the participants did not know the reasons for seeking immediate treatment for the problems.

\section{Knowledge related to postpartum period}

Just over half $18(54.5 \%)$ of the participants could identify problems after delivery but the frequency of the identified problems were low (see Table 4).

Eight (24\%) of the participants mentioned postpartum haemorrhage (PPH). This finding is consistent with the findings of a participatory needs assessment done in two districts in Malawi, where bleeding was mentioned as a complication by only $18 \%$ of the women. The exception is that in this study $10(30 \%)$ of the participants identified sepsis, which was not mentioned in the needs assessment study (Safe Motherhood Project 1998: 15). In response to problems that needed immediate treatment three participants stated that they did not know any. Postpar- 
tum haemorrhage was the complication most frequently mentioned. Other complications mentioned and their frequencies are illustrated in Fig. 3.

All of the problems in Fig. 3 require immediate treatment because they can result in the death of the mother. It is therefore of concern that identification of problems requiring immediate treatment was generally low except for PPH. It can be assumed that because the participants were not aware of these complications (refer Table 4) in the first place, it was unrealistic for them to have information about its management. However, as already stated, information needs to be provided in such a way that it focuses on the types of obstetric complications and their management. The primigravidae should know when and where to go when an obstetric complication occurs. This may prevent delays in seeking care at health facilities with complications that need emergency obstetric care.

The reasons given for seeking immediate treatment for complications after delivery were promotion of women's well-being $(n=5)$, prevention of ill-health $(n=7)$ and death of the mother $(n=17)$. It can be seen here again that preventing death of the woman was the reason that was frequently mentioned by most participants, $17(51.5 \%)$, for seeking immediate treatment compared to the rest. Six (18\%) participants did not know the reasons for seeking immediate treatment.

All participants reported that they would go to the hospital. However, only six (18\%) participants stated that they would go quickly to the hospital. This contrasts with 11 (33\%) participants who stated that they would go quickly to the hospital if they experienced problems during pregnancy. Gennaro et al. (1998: 194) state that postpartum care is not valued. They stated that a comment made regarding postpartum care was, "The baby is already born, so what is the point?" However it is important for the primigravidae to understand the importance of early management of maternal complications during the puerperium. Haemorrhage and sepsis account for $48 \%$ of maternal deaths in Malawi, both at $24 \%$ respectively. Primigravidae need to be informed about likely postpartum problems in order for them to recognise the problems and access care promptly. This is significant because it has been noted that women are discharged postnatally with inadequate advice about possible problems, such as fever, offensive discharge or continued bleeding (Malawi Safe Motherhood Programme undated: 27). In addition, $75 \%$ of maternal deaths globally, occur in the postpartum period (UNICEF 1999: 19).

Sixty-one percent (95\% confidence interval: $42-79$ ) of the primigravidae had some knowledge and could make an informed decision to go to the hospital.

The majority, $28(84.8 \%)$, of the participants reported that they had received some information about pregnancy problems compared with $18(54.5 \%$ ) who had information on childbirth problems. This finding is reflected in the participants responses during the study, in that $28(84.8 \%)$ of the participants stated that they knew complications that could occur in pregnancy. This is in contrast to $19(57.5 \%)$ and $15(45.5 \%)$ of the participants, who did not know of any complications that could occur during the birth and after the birth of the baby. This lack of awareness of complications which could occur, may result in the primigravidae not seeking immediate care for complications that need emergency treatment.

\section{Limitations}

The use of only primigravidae who attended antenatal clinics limits the generalisability of the findings to primigravidae who do not attend antenatal clinics, as well as to multigravidae. Purposive sampling limited a wider representation of pregnant women as they did not have an equal chance for inclusion. Therefore, generalisation of the results to other primigravidae is limited. Polit and Hungler (1997: 230) note that it is risky to generalise findings from a purposive sample to a broader population. The data were based on the women's ability to recall what they knew and they may not have remembered, although they were informed. The findings, therefore, should be approached with caution.

\section{Recommendations Midwifery practice}

When providing information, there is need to make a clear distinction between minor disorders of pregnancy and obstetric complications to enable women to differentiate the two. Information on obstetric complications needs to be provided to the women and the community in a manner that covers all three time periods (antepartum, intrapartum and postpartum). In addition there is need to emphasise which obstetric complications need immediate treatment and why. These complications should be written on the maternal card in the local language, to remind the women about them. The community needs to be empowered with knowledge on obstetric complications. This is important, because from the findings of this study women start attending antenatal care late.

\section{Midwifery education}

The midwifery curriculum needs to have a strong component of Safe Motherhood and life-saving knowledge and skills. This will enable students and graduates of the programme to provide care effectively. Students need to be taught how to impart health education/information. Learning how to give information is a very important aspect of a health professional's development. Refresher courses to update health personnel on current issues about Safe Motherhood need to be conducted. This could ensure the appropriate provision of care.

\section{Midwifery Research}

There is a need to assess the extent to which IEC about obstetric complications is improving women's and communities' ability to appropriately seek care. If not, the hindering factors need to be identified and addressed for the information to have an impact. The study needs to be replicated to include multigravidae and using a larger sample. This will allow for comparison between the groups.

\section{Conclusion}

The majority ( $94 \%$ ) of the women had booked into the antenatal clinic during the second and third trimesters of preganacy, thus limiting the opportunity for antenatal education. Furthermore, $45 \%$ of the women stated that they had experienced problems during their pregnancies. Most of the participants knew about obstetric complications in pregnancy in contrast with complications during the birth and after the birth of the baby. The most frequently cited complication of pregnancy was vaginal bleeding, whilst hypertension was the fourth most fre- 
quently cited complication. Excessive or heavy bleeding was the most commonly mentioned complication of labour, whilst sepsis and postpartum haemorrhage were the most frequently mentioned complications of the puerperium. Likewise, knowledge appeared to be better of complications that need immediate treatment in pregnancy as compared with that during and after labour. Since the majority of women appear to book into antenatal late in their pregancies and because knowledge of complications of the intrapartum and postpartum periods is poor, alternate ways of communicating information to women and the community need to be explored.

\section{References}

ABOUZAHR. C; WARDLAW, T; STANTON, C \& HILL, K 1996: Maternal mortality. World Health Statistics Quarterly. 49: $77-87$.

ABOUZAHR,C 2000: OECD Observer: "Maternal mortality: helping mothers live." <http://oecdobserver.org/news/ Fullstory.php/aid/374> (1 November 2001).

"ADOLESCENCE AND PREGNANCY." < http: // www. hsph.harvard.edu.grhf/ Sasia/ forums/ Nutrition/ Nutrition/ 4 ADOLELE.HTM> (25 May 2001).

ALISJAHBANA, A; WILLIAMS, C; DHARMAYANTI, R; HERMAWAN, D; KWAST, BE \& KOBLINSKY, B 1995: An integrated village maternity service to improve referral patterns in a rural area in West Java.Int. J. Gynaecol. Obstet. 48, Suppl. : 83-94.

BENNET, VR \& BROWN LK Eds. 1999: Myles Textbook for Midwives $13^{\text {th }}$ ed. Edinburgh: Livingstone.

BHATIA, JC "Levels and causes of maternal mortality in Southern India." < http: // www.hsp.harvard.edu./grhf/Sasia/ Suchana/ 0628/ bhatia. Html> (25 May 2001).

CASTRO, R; CAMPERO, L; HERNANDEZ, B \& LANGER, A 2000: A study on maternal mortality in Mexico through a qualitative approach. Journal of Women's Health and Gender Based Medicine. 9(6) : 679-691.

GENNARO, S; KAMWENDO, L; MBWEZA, E \& KERSHBAUMER R 1998: Childbearing in Malawi, Africa. Journal of Obstetric, Gynaecologic and Neonatal Nursing. 27 (2) : $191-196$.

GUMMI, FB; HASSAN, M; SHEHU, D \& AUDU, L 1997: Community Education to encourage use of emergency obstetric services. Kebbi State, Nigeria. Int. J. Gynaecol. Obstet. 59 Suppl. $2: 191-200$.

KUATE DEFO, B 1997: Effects of socioeconomic disadvantage and women's status on women's Health in Cameroon. Social Science Medicine. 44 (7) : 1023 -1042.

KWAST, BE 1995: Building a community-based maternity programme. Int. J. Gynaecol. Obstet. vol. 48 Suppl. : 67 -82.
LALONDE, AB 1998: Safe motherhood: can we make a difference? Canadian Medical Association. 158 (no) $7: 889$ -891 .

MALAWI NATIONAL SAFE MOTHERHOOD PROGRAMME undated: Malawi National Strategic Plan for Safe Motherhood. Ministry of Health and Population. Lilongwe, Malawi.

MALAWISAFEMOTHERHOODPROGRAMME, MALAWI SAFE MOTHERHOOD PROJECT AND MINISTRY OF HEALTH AND POPULATION. 2000 Obstetric life skills training manual for Malawi. Lilongwe, Malawi

MATERNAL HEALTH AND SAFE MOTHERHOOD PROGRAMME 1994. Mother-Baby Package: Implementing Safe Motherhood in countries. WHO, Geneva.

MATINGA , PU 1998: Improving quality and access to maternal health services for Malawian women: a participatory needs assessment for Blantyre and Nsanje. Safe Motherhood Project, Blantyre, Malawi.

MINISTRY OF HEALTH AND POPULATION 1996: Safe Motherhood Needs Assessment Report. Lilongwe, Malawi.

MWANZA DISTRICT HOSPITAL 1999: A situational analysis on cbstetrical referral compliance: a qualitative and quatitative study determining compliance rates and factors affecting referral compliance in Mwanza District. Blantyre, Malawi.

NATIONAL STATISTICAL OFFICE 1994: Malawi Demographic and Health Survey_1992. Zomba, Malawi.

NGAIYAYE, R\& SAFEMOTHERHOODPROJECT undated: Safe Motherhood Media Tool Kit: Booklet for media practitioners in Malawi. Ministry of Health and Population, Lilongwe, Malawi.

OLANIRAN N; OFFIONG, S; OTTONG, J; ASUQUO, J \& DUKE, F 1997: Mobilizing the community to utilize obstetric services, Cross River State, Nigeria. Int. J. Gvnaecol. Obstet. 59 Suppl. 2 : 181 - 189 .

OPUKU, SA; KYEIFARIED, S; TWUM, S; DJAN, JO; BROWNE, ENL \& BONNEY, J 1997: Community education to improve utilisation of emergency obstetric services in Ghana. Int. J. Gynaecol.Obstet. 59 Suppl. 2 : 201 -207.

MATINGA , PU 1998: Improving quality and access to maternal health services for Malawian women: a participatory needs assessment for Blantyre and Nsanje. Safe Motherhood Project, Blantyre, Malawi.

MINISTRY OF HEALTH AND POPULATION 1996: Safe Motherhood Needs_Assessment Report. Lilongwe, Malawi.

MWANZA DISTRICT HOSPITAL 1999: A situational analysis on obstetrical referral compliance: a qualitative and quatitative study determining compliance rates and factors affecting referral compliance in Mwanza District. Blantyre, Malawi. 
NATIONAL STATISTICAL OFFICE 1994: Malawi Demographic and Health Survey_1992. Zomba, Malawi.

NGAIYAYE, R \& SAFEMOTHERHOODPROJECT undated: Safe Motherhood Media Tool Kit: Booklet for media practitioners in Malawi, Ministry of Health and Population, Lilongwe, Malawi.

OLANIRAN N; OFFIONG, S; OTTONG, J; ASUQUO, J \& DUKE, F 1997: Mobilizing the community to utilize obstetric services, Cross River State, Nigeria. Int. J. Gynaecol. Obstet. 59 Suppl. 2 : 181 - 189.

OPUKU, SA; KYEI-FARIED, S; TWUM, S; DJAN, JO; BROWNE, ENL \& BONNEY, J 1997: Community education to improve utilisation of emergency obstetric services in Ghana. Int. J. Gvnaecol. Obstet. 59 Suppl. $2: 201-207$.

POLIT, DF \& HUNGLER, BP 1997: Essentials of Nursing Research : Methods, Appraisal_and Utilisation $4^{\text {th }}$ ed. Philadelphia: J.B. Lippincott Co.

POST, M 1997: "Preventing maternal mortality through obstetric care." <http: //www.info.usaid.gov/regions/afr/hhraa/ eoc.htm> (25 May 2001).

SAFE MOTHERHOOD FACT SHEET: "Adolescent sexuality and childbearing." <http: // www.safemotherhood.org/ fac..._figures/adolescent_sexuality.htm> (27August 2001).

SAFE MOTHERHOOD FACT SHEET: "Maternal mortalty" <http: // www.safemotherhood. org/facts_and_figures/ maternal_mortality.htm> (1 November 2001).

SAFE MOTHERHOOD PROJECT 1998: Participatory needs assessment results: Summary document for Blantyre and Nsanje districts. Blantyre, Malawi.

SAFE MOTHERHOOD PROJECT 1999: Participatory needs assessment results (draft): Zomba Phalombe and Chiradzulu, Blantyre, Malawi.

SAFE MOTHERHOOD PROJECT 1999: Qualitative needs assessment report: Zomba, Phalombe and Chiradzulu, Blantyre, Malawi.

SHANE, B 1997: Family Planning Saves Lives, $3^{\text {rd }}$ ed. Washington: Population Reference Bureau.

SIMPSON, H 1998: Quality of care study: A qualitative and quantitative study exploring users; health staff and managers satisfaction with obstetric services offered in Blantyre and Nsanje districts in the Southern region of Malawi. Safe Motherhood Project. Blantyre, Malawi.

THADDEUS, S \& MAINE, D 1994: Too far to walk: maternal mortality in context. Social Science Medicine. $8: 1091-1110$.

THEMMEN, E 1995: Essential obstetric care: Community awareness, involvement and support. In: A report of a technical meeting of the Inter - Agency Group for safe motherhood.
UNICEF 1999: Programming for safe motherhood: Guidelines for maternal and neonatal_survival. New York: Total Concept Graphics.

VERMA, V \& DAS, KB "Teenage primigravidae: A comparative study". <http:// www.hsph.harvard.edu/ grhf/ Sasia/ forums/ Nutrition/ Nutrition S006. HTM > (2 June 2001)

\section{WORLD HEALTH ORGANISATION AND WORLD BANK} 1997: Maternal Health_Around the World Poster. Geneva.

WORLD HEALTH ORGANISATION 1999: Reduction of maternal mortality: A joint WHO/ UNFPA/UNICEF/ World Bank statement. Geneva

POLIT, DF \& HUNGLER, BP 1997: Essentials of Nursing Research : Methods, Appraisal_and Utilisation $4^{\text {th }}$ ed. Philadelphia: J.B. Lippincott Co.

POST, M 1997: "Preventing maternal mortality through obstetric care." <http: //www.info.usaid.gov/regions/afr/ hhraa/eoc.htm> (25 May 2001).

SAFE MOTHERHOOD FACT SHEET: "Adolescent sexuality and childbearing." <http: //www.safemotherhood.org/ fac..._figures/adolescent_sexuality.htm> (27August 2001).

SAFE MOTHERHOOD FACT SHEET: "Maternal mortalty" <http: // www.safemotherhood. org/facts_and_figures/ maternal_mortality.htm> (I November 2001).

SAFE MOTHERHOOD PROJECT 1998: Participatory needs assessment results: Summary document for Blantyre and Nsanje districts. Blantyre, Malawi.

SAFE MOTHERHOOD PROJECT 1999: Participatory needs assessment results (draft): Zomba Phalombe and Chiradzulu, Blantyre, Malawi.

SAFE MOTHERHOOD PROJECT 1999: Qualitative needs assessment report: Zomba, Phalombe and Chiradzulu Blantyre, Malawi.

SHANE, B 1997: Family Planning Saves Lives, $3^{\text {rd }}$ ed. Washington: Population Reference Bureau.

SIMPSON, H 1998: Quality of care study: A qualitative and quantitative study exploring users; health staff and managers satisfaction with obstetric services offered in Blantyre and Nsanje districts in the Southern region of Malawi. Safe Motherhood Project. Blantyre, Malawi.

THADDEUS, S \& MAINE, D 1994: Too far to walk: maternal mortality in context. Social Science Medicine. $8: 1091-1110$

THEMMEN, E 1995: Essential obstetric care: Community awareness, involvement and support. In: A report of a technical meeting of the Inter - Agency Group for safe motherhood.

UNICEF 1999: Programming for safe motherhood: Guidelines for maternal and neonatal_survival. New York: Total Concept Graphics. 
VERMA, V \& DAS, KB "Teenage primigravidae: A comparative study". <http:// www.hsph.harvard.edu/ grhf/ Sasia/ forums/Nutrition/ Nutrition S006. HTM> (2 June 2001)

\section{WORLD HEALTH ORGANISATION AND WORLD BANK}

1997: Maternal Health_Around the World Poster. Geneva.

WORLD HEALTH ORGANISATION 1999: Reduction of maternal mortality: A joint WHO/ UNFPA/UNICEF/ World Bank statement. Geneva 